\title{
PENGEMBANGAN MEDIA PEMBELAJARAN VISUAL DENGAN MENGGUNAKAN FLIPCHART UNTUK MENINGKATKAN MOTIVASI BERPRESTASI MELALUI LAYANAN BIMBINGAN KELOMPOK
}

\author{
Happy Karlina Marjo ${ }^{1}$ \\ Auliya Safitri ${ }^{2}$
}

\begin{abstract}
Abstrak
Penelitian ini bertujuan menghasilkan media pembelajaran visual dengan menggunakan flipchart untuk meningkatkan motivasi berprestasi melalui layanan bimbingan kelompok peserta didik kelas $\mathrm{X}$ di SMAN 11 Jakarta. Peneliti menggunakan teknik cluster sampling dengan memilih 6 kelas dengan jumlah populasi dan sampel secara keseluruhan yaitu 198 peserta didik kelas X. Metode penelitian yang digunakan merupakan metode pengembangan Research and Development $(R \& D)$ menggunakan model ADDIE (Analyze, Design, Develop, Implement, dan Evaluate). Adapun tahapan model pengembangan yang dilakukan adalah analisis, desain, dan pengembangan. Alat pengumpul data berupa angket dan wawancara. Penilaian media dilakukan oleh validator yang terdiri dari ahli media, ahli materi dan peserta didik. Berdasarkan data tersebut menunjukkan bahwa hasil evaluasi formatif yang dilakukan oleh ahli media $95 \%$, penilaian ahli materi $98 \%$, dan penilaian peserta didik mencapai $95 \%$. Hasil media pembelajaran visual dengan menggunakan flipchart untuk meningkatkan motivasi berprestasi melalui layanan bimbingan kelompok pada 10 peserta didik kelas X di SMAN 11 Jakarta yaitu 100\% peserta didik mengetahui motivasi berprestasi dan $100 \%$ peserta didik menyatakan media flipchart adalah media yang mampu menyajikan pembelajaran secara ringkas dan praktis. Media pembelajaran visual dengan menggunakan flipchart untuk meningkatkan motivasi berprestasi melalui layanan bimbingan kelompok peserta didik kelas X di SMAN 11 Jakarta dikategoriikan sangat baik untuk menjadi media pembelajaran yang cocok untuk peserta didik yang memiliki gaya belajar visual.
\end{abstract}

Kata Kunci: Media Pembelajaran, Visual, Flipchart, Motivasi Berprestasi, Bimbingan Kelompok.

\begin{abstract}
This study aims to produce visual learning media by using flipcharts to improve achievement motivation through class $X$ student group guidance services at SMAN 11 Jakarta. The researcher used cluster sampling technique by selecting 6 classes with the total population and sample as a whole, namely 198 class $X$ students. The research method used was the Research and Development $(R \& D)$ development method using ADDIE (Analyze, Design, Develop, Implement, and Evaluate) models. The stages of the development model carried out are analysis, design and development. Data collection tools in the form of questionnaires and interviews. The media assessment is carried out by a validator consisting of media experts, material experts and students. Based on these data shows that the results of the formative
\end{abstract}

\footnotetext{
${ }^{1}$ Univeristas Negeri Jakarta, hkarlina@unj.ac.id

2 Univeristas Negeri Jakarta, auliya.safitri35@gmail.com
} 
evaluation carried out by media experts $95 \%$, the assessment of material experts $98 \%$, and the assessment of students reached $95 \%$. The results of visual learning media by using flipcharts to improve achievement motivation through group guidance services at 10 class X students in SMAN 11 Jakarta, namely 100\% of students know achievement motivation and 100\% of students say flipchart media is a medium that is able to present learning in a concise and practical manner. Visual learning media by using flipcharts to improve achievement motivation through class $X$ student group guidance services at SMAN 11 Jakarta are categorized as very good to be a learning medium suitable for students who have a visual learning style.

Keywords: Learning Media, Visual, Flipchart, Achievement Motivation, Group Guidance.

Pendidikan adalah segala pengalaman (belajar) di berbagai lingkungan yang berlangsung sepanjang hayat dan berpengaruh positif bagi perkembangan individu. Pendidikan hanya berlangsung bagi mereka yang menjadi peserta didik di sekolah atau mahasiswa di perguruan tinggi (lembaga pendidikan formal). Pendidikan dilakukan dalam bentuk pengajaran yang terprogram dan bersifat formal. Pendidikan berlangsung di sekolah atau di dalam lingkungan tertentu yang diciptakan secara sengaja dalam konteks kurikulum sekolah yang bersangkutan.

Sudah selayaknya lahir generasigenerasi membanggakan dari pendidikan nasional. Peserta didik diharapkan mampu menjadikan pengalaman hidupnya bersama keluarga, teman, masyarakan, lingkungan sekitar, dan alam sebagai pembelajaran penting yang berharga dan menjadikan pendidikan formalnya sebagai sarana mengembangkan kemampuan-kemampuan, sehingga mampu memiliki prestasi yang membanggakan.

Terkait dengan prestasi dalam pendidikan, ada salah satu hal yang penting untuk dibahas, yaitu motivasi berprestasi. Motivasi beprestasi penting bagi bimbingan kelompok agar peserta didik memahami bagaimana cara mencapai suatu tujuan dalam konteks prestasi. Peserta didik yang memiliki motivasi berprestasi akan melakukan sesuatu dengan lebih baik agar mencapai kesuksesa. Motivasi berprestasi penting bagi peserta didik untuk mencapai sebuah kompetensi pengembangan pribadi dalam standar kompetensi kemandirian peserta didik (SKKPD). Kompetensi pengembangan pribadi dalam ranah belajar bertujuan agar peserta didik mempelajari keunikan dan kemampuan diri sendiri dalam konteks belajar. Motivasi berprestasi peserta didik di Indonesia tergolong rendah. Data menunjukkan bahwa $40.4 \%$ peserta didik memiliki motivasi rendah, $33.3 \%$ sedang, dan $26.2 \%$ tinggi. Perlu digali lebih dalam tentang motivasi berprestasi (Suarni, 2004)

Studi pendahuluan dilakukan untuk menemukan permasalahan terkait motivasi berprestasi di SMA Negeri 11 Jakarta. Alat pengumpul data yang digunakan yaitu kuesioner yang akan diberikan kepada peserta didik kelas $\mathrm{X}$ dengan jumlah responden sebanyak 198 peserta didik yang terdiri dari kelas X IPS 1, X IPS 2, X IPS 3, X IPA 1, X IPA 2, dan X IPA 3. Motivasi penting dalam bimbingan kelompok, hasil dari studi pendahuluan tersebut yaitu sebesar 41 peserta didik $(21 \%)$ atau sebagian kecil mengetahui mengenai motivasi berprestasi dan 13 peserta didik (7\%) atau sebagian kecil menyatakan guru bimbingan dan konseling memberikan materi mengenai motivasi berprestasi.

Konten-konten yang perlu peneliti masukan dalam media pembelajaran visual dengan menggunakan flipchart untuk meningkatkan motivasi berprestasi berdasarkan hasil studi pendahulan dengan urgensi tertinggi yaitu 191 peserta didik (97\%) atau hampir seluruhnya menyatakan enggan berkompetisi dengan teman-teman untuk mendapatkan nilai tertinggi dikela, 158 peserta didik (80\%) atau hampir seluruhnya menyatakan enggan mempelajari 
bahasa asing yang tidak dimengerti, 148 peserta didik $(75 \%)$ atau hampir seluruhnya menyatakan hanya menunggu pemberitahuan dari guru tentang hal-hal yang harus dipersiapkan dalam menghadapi ujian, 123 peserta didik (62\%) atau sebagian besar menyatakan mengumpulkan tugas seadanya tanpa memikirkan bagaimana hasilnya nanti, 108 peserta didik (55\%) atau sebagian besar menyatakan tidak memeriksa kembali pekerjaan rumah setelah dinilai guru.

Usaha perbaikan dalam layanan bimbingan kelompok yang dilakukan di SMA Negeri 11 Jakarta agar peserta didik mendapatkan kebutuhan informasi mengenai materi motivasi berprestasi. Usaha tersebut dapat dilakukan dengan mengembangkan sebuah media pembelajaran yang menarik, menyenangkan dan mudah dimengerti oleh peserta didik dalam pembelajaran. Salah satunya dapat diwujudkan dengan mengembangnkan media pembelajaran visual flipchart yang diharapkan mampu membantu peserta didik dalam memahami materi motivasi berprestasi.

Studi pendahuluan dilakukan dengan memberikan kuesioner kepada responden yang sama yaitu peserta didik kelas $\mathrm{X}$ dengan jumlah responden sebanyak 198 peserta didik yang terdiri dari kelas X IPS 1 , X IPS 2, X IPS 3, X IPA 1, X IPA 2, dan X IPA 3 di SMA Negeri 11 Jakarta mengenai media pembelajaran flipchart. Hasil studi pendahuluan mengenai media pembelajaran flipchart menyatakan $7 \%$ peserta didik atau sebagian kecil yang mengetahui media pembelajaran flipchart, $41 \%$ peserta didik atau hampir seluruhnya menyatakan media Flipchart adalah media yang mampu menyajikan pembelajaran secara ringkas dan praktis, $68 \%$ peserta didik menyatakan media flipchart adalah media yang fleksibel (dapat digunakan diluar ruangan maupun didalam ruangan), $7 \%$ peserta didik mengetahui cara menggunakan media flipchart.

Kenyataannya di SMA Negeri 11 Jakarta fasilitas pembelajaran seperti $L C D$ dan proyektor tersedia hanya dibeberapa kelas XI dan kelas XII dan untuk kelas X fasilitas pembelajaran tidak berfungsi dengan baik bahkan ada beberapa kelas $\mathrm{X}$ yang tidak ada $L C D$ dan proyektor. Dengan menggunakan media pembelajaran flipchart, guru bimbingan dan koseling tidak perlu menggunakan $L C D$ dan proyektor karena media pembelajaran flipchart adalah media pembelajaran visual yang tidak memerlukan arus listrik.

Penyampaian informasi media pembelajaran visual menggunakan flipchart untuk meningkatkan motivasi berprestasi dilakukan melalui layanan bimbingan kelompok dikarenakan keterbatasan flipchart yang dikembangkan oleh peneliti adalah ukuran flipchart hanya $29,7 \mathrm{~cm}$ x $42 \mathrm{~cm}$. Layanan bimbingan kelompok membuat penyampaian materi motivasi berprestasi lebih efektif dan efisien dikarenakan peserta bimbingan kelompok hanya 8 sampai 15 peserta didik.

Peneliti mengembangkan media flipchart karena media flipchart memiliki keunggulan dari media lainnya. Jika dibandingkan dengan media audio dan media audio visual seperti video, media flip chart lebih murah, lebih praktis, peserta didik dapat membuat sendiri. Media audio dan media audio visual seperti video atau media-media canggih hanya dapat digunakan di tempat tertentu. Tetapi, media pembelajaran flipchart dapat digunakan dalam kondisi sekolah yang tidak mempunyai alat-alat canggih seperti proyektor, lcd, dan laptop.

\section{Media Pembelajaran}

Association for Education and Communication Technologi (AECT) megartikan media sebagai segala bentuk yang digunakan untuk proses penyaluran informasi. Sedangkan Education Association (NEA) mengartikan media sebagai benda yang dapat dimanipulasi, dilihat, didengar dibaca atau dibicarakan beserta instrument yang dipergunakan dengan baik dalam kegiatan belajar 
mengajar, dapat mempengaruhi efektifitas program instruksional (Usman, 2002).

\section{Media Visual}

Media visual merupakan media yang menggunakan indera penglihatan. Media visual adalah suatu konteks yang bermakna bagi peserta didik untuk berinteraksi dan menimbulkan terjadinya proses informasi. Media visual menggunakan gambar atau tampaknya suatu benda dalam sebuah pembelajaran, sehingga dapat memperlancar pemahaman belajar peserta didik dan membuat pembelajaran menjadi efektif (Arsyad, 2013).

\section{Flipchart}

Flipchart adalah lembaran-lembaran kertas yang menyerupai album atau kalender yang berukuran $50 \times 75 \mathrm{~cm}$ atau ukuran yang lebih kecil 29,7 $\times 42 \mathrm{~cm}$ sebagai flipbook yang disusun dalam urutan yang diikat pada bagian atasnya atau dapat disesuaikan dengan besar kecilnya kelas yang dihadapi. Flipchart memiliki dudukan atau penyangga khusus, atau dapat digantung pada sebuah paku dengan menggunakan tali (Susilana \& Riyana, 2008).

Flipchart adalah kumpulan ringkasan, skema, gambar, table yang dibuka secara berurutan berdasarkan topik materi pembelajaran. Bahan flipchart biasanya kertas ukuran plano yang mudah dibukabuka, mudah ditulisi, dan berwarna cerah. Daya tarik flipchart dapat dicetak dengan aneka warna dan variasi desainnya.

\section{Motivasi Berprestasi}

Motivasi berprestasi sebagai usaha untuk melakukan sesuatu dengan lebih baik agar mencapai sukses dan keberhasilan dalam kompetisi sesuai dengan standar keunggulan (McClelland, 1987). Motivasi berprestasi (achievement motivation) sebagai suatu motivasi intrinsik atau daya penggerak dalam diri seseorang untuk mencapai prestasi belajar setinggi mungkin demi penghargaan terhadap dirinya sendiri (Winkel, 2000).

\section{METODE PENELITIAN}

Metode penelitian yang digunakan dalam penelitian ini adalah Penelitian dan Pengembangan (Research and Development). Menghasilkan produk tertentu digunakan penelitian yang bersifat analisis kebutuhan (digunakan metode survey atau kualitatif) dan untuk menguji keefektifan produk tersebut supaya dapat berfungsi di masyarakat luas, maka diperlukan penelitian untuk menguji keefektifan produk tersebut (digunakan metode eksperimen) (Sugiyono, 2009). Model ADDIE tersusun dari lima tahapan proses, yaitu: Analisis, Desain, Pengembangan, Implementasi dan Evaluasi. ADDIE merupakan sebuah model yang dikembangkan dari model ID (Instructional Design) yang digunakan untuk tujuan pengembangan landasan teoritis dan pembelajaran.

Populasi dalam penelitian ini ada peserta didik kelas $\mathrm{X}$ di SMA Negeri 11 Jakarta sejumlah 198 orang peserta didik. Adapun populasi dalam penelitian ini yaitu peserta didik kelas X di SMA Negeri 11 Jakarta. Adapun detail jumlah peserta didik tiap kelas yaitu kelas X IPS 1 sebanyak 29 peserta didik, X IPS 2 sebanyak 34 peserta didik, X IPS 3 sebanyak 35 peserta didik, X IPA 1 sebanyak 31 peserta didik, X IPA 2 sebanyak 34 peserta didik, dan X IPA 3 sebanyak 34 peserta didik. Jika dijumlahkan total seluruh peserta didik pada kelas $\mathrm{X}$ yaitu sebanyak 198 peserta didik.

Sampel yang digunakan oleh peneliti adalah menggunakan stratified cluster sampling. Teknik stratified cluster sampling digunakan bilamana populasi tidak terdiri dari individu-individu, melainkan terdiri dari kelompok-kelompok individu atau cluster. Teknik sampling daerah digunakan untuk menentukan sampel bila objek yang akan diteliti atau sumber data sangat luas, misalnya penduduk dari suatu negara, propinsi atau kabupaten (Margono, 2004). Sampel yang digunakan peneliti yaitu menggunakan rumus Slovin seperti dibawah ini: 


$$
n=\frac{N}{N \cdot d^{2}+1}
$$

\section{Keterangan:}

$\mathrm{n}=$ Jumlah Sampel

$\mathrm{N}=$ Jumlah Populasi

$\mathrm{d}=$ Determinant $($ batas toleransi error $=0,05$ )

\section{$\underline{\text { Jumlah Kelas }}$}

Jumlah kelas $=\frac{N}{N \cdot d^{2}+1}:=\frac{6}{6 \cdot(0,05)^{2}+1}=5,91(6)$

Total $=6$ kelas

Jumlah peserta didik untuk sampel: 198 peserta didik.

\section{HASIL PENELITIAN}

Analisis terdiri dari beberapa tahapan yaitu: 1) Validasi Kesenjangan: peneliti mengukur kesenjangan dengan melakukan wawancara kepada guru bimbingan dan konseling serta menyebarkan angket untuk meningkatkan media pembelajaran flipchart untuk meningkatkan motivasi berprestasi melalui layanan bimbingan kelompok yang ditujukan kepada peserta didik SMA Negeri 11 Jakarta kelas X dengan jumlah responden sebanyak 198 peserta didik. Hasil dari studi pendahuluan tersebut yaitu sebesar sebesar 20\% (40 peserta didik) atau sebagian kecil mengetahui untuk meningkatkan motivasi berprestasi, 7\% (13 peserta didik) atau sebagian kecil menyatakan guru bimbingan dan konseling memberikan materi untuk meningkatkan motivasi berprestasi.

Pada analisis kebutuhan peneliti menyebarkan kuesioner kepada peserta didik dan wawancara kepada guru bimbingan dan konseling. Hasil dari penyebaran kuesioner dengan menggunakan stratified cluster sampling kepada 198 orang peserta didik maka diperoleh hasil sebagai berikut: a) 191 peserta didik (97\%) atau hampir seluruhnya menyatakan enggan berkompetisi dengan teman-teman untuk mendapatkan nilai tertinggi dikelas, b) 158 peserta didik (80\%) atau hampir seluruhnya menyatakan enggan mempelajari bahasa asing yang tidak dimengerti, c) 148 peserta didik $(75 \%)$ atau hampir seluruhnya menyatakan hanya menunggu pemberitahuan dari guru tentang hal-hal yang harus dipersiapkan dalam menghadapi ujian, d) 123 peserta didik (62\%) atau sebagian besar menyatakan mengumpulkan tugas seadanya tanpa memikirkan bagaimana hasilnya nanti, f) 108 peserta didik (55\%) atau sebagian besar menyatakan tidak memeriksa kembali pekerjaan rumah setelah dinilai guru, g) 7\% (13 peserta didik) atau sebagian kecil yang mengetahui media pembelajaran flipchart, h) 41\% (80 peserta) didik atau hampir seluruhnya menyatakan media Flipchart adalah media yang mampu menyajikan pembelajaran secara ringkas dan praktis, i) $68 \%$ (133 peserta didik) menyatakan media flipchart adalah media yang fleksibel (dapat digunakan diluar ruangan maupun didalam ruangan), j) $7 \%$ (13 peserta didik) mengetahui cara menggunakan media flipchart. 2) Menentukan tujuan instruksional: dalam penelitian terdapat beberapa tujuan a) Peserta didik dapat memahami definisi motivasi berprestasi, b) Peserta didik dapat memahami ciri-ciri motivasi berprestasi, c) Peserta didik dapat mengenali jenis-jenis motivasi berprestasi, d) Peserta didik dapat memahami faktor-faktor yang mempengaruhi motivasi berprestasi, e) Peserta didik dapat memahami fungsi motivasi dalam berprestasi, f) Peserta didik mampu mengenali upaya untuk meningkatkan motivasi berprestasi dengan benar. 3) Menentukan pengguna yang dituju: Target pengguna dalam penelitian adalah peserta didik SMA kelas X dan Lakilaki/Perempuan dengan rentang usia 16-17 tahun. 4) Identifikasi sumber yang diperlukan: Diperlukan beberapa sumber pendukung dalam proses pengembangan yang akan dilakukan, diantaranya: a) Art Karton ukuran 29,7x42 cm sebanyak 9 lembar, b) Art Paper ukuran 29,7x42 cm sebanyak 9 lembar, c) Kertas HVS sebanyak 8 lembar, d) Mika lembaran bening, e) Spiral sebanyak 1 buah, f) Double tape.

Desain terdiri dari beberapa tahapan yaitu 1) Melakukan inventori tugas: a) Peserta didik dapat memahami pengertian, 
ciri-ciri, jenis-jenis, faktor-faktor, dan fungsi motivasi motivasi berprestasi. Tujuan tersebut akan didukung dengan materi yang ada didalam media pembelajaran flipchart yang ada pada lembaran ketiga sampai kedelapan, b) Peserta didik dapat memahami upaya untuk meningkatkan motivasi berprestasi. 2) Menyusun sasaran kinerja: Dalam menentukan tujuan penampilan, maka peneliti membuat beberapa soal yang dikembangkan guna mengukur ketercapaian tujuan. Soal-soal tersebut yakni: a) Apa yang dimaksud motivasi berprestasi? b) Sebutkan ciri-ciri peserta didik yang mempunyai motivasi berprestasi? c) Sebutkan jenis-jenis motivasi berprestasi? d) Sebutkan faktorfaktor yang mempengaruhi motivasi berprestasi? e) Apa saja fungsi motivasi dalam belajar? f) Sebutkan upaya apa saja untuk meningkatkan motivasi berprestasi.

Pengembangan terdiri dari beberapa tahapan yaitu: 1) Menghasilkan konten: Pada tahap ini peneliti menghasilkan konten berupa: a) Meringkas materi, b) Membuat kerangka media flipchart, c) Pembuatan media pembelajaran fliphchart, peneliti membuat media pembelajaran flipchart dengan ketentuan sebagai berikut: (1) Memilih Art carton, Art paper, spiral sebagai bahan dasar media pembuatan flipchart. (2) Art carton dan Art paper berukuran 29,7 (panjang) x 42 (lebar) $\mathrm{cm}$. (3) Desain frame dan flipchart yang dikerjakan oleh ilustrator. Cover flipchart dimasukan dengan beberapa konten yang tercantum pada bagian depan produk antara lain logo beserta nama instansi yang menaungi peneliti yaitu Universitas Negeri Jakarta, "Flipchart Motivasi Berprestasi" sebagai judul produk, Auliya Safitri sebagai nama pembuat produk dan BK A 2014 sebagai identitas pembuat produk. (4) Warna frame flipchart orange, warna dasar flipchart orange muda, slide materi flipchart berwarna hijau neon, hijau pastel, dan hijau tosca (5) Warna tulisan kontras dengan layout agar mudah dibaca. (6) Font setiap lembaran flipchart. 2) Memilih atau mengembangkan media pendukung: a)
Tahap pra produksi, pada tahap pengembangan media flipchart dimulai dengan langkah pertama yaitu membuat kerangka media flipchart. Lalu menentukan bahan dan kertas yang akan digunakan dalam pembuatan flipchart. Selanjutnya meringkas materi motivasi berprestasi sesuai dengan tujuan pembelajaran, b) Tahap produksi, eneliti menentukan warna frame flipchart,warna huruf dan ukuran huruf frame flipchart, warna cover flipchart, warna disetiap lembaran flipchart dan ukuran serta warna huruf disetiap lembaran flipchart. Peneliti juga menentukan gambar yang akan dimasukan kedalam flipchart. Pada tahap produksi, peneliti dibantu illustrator untuk mengerjakan proses gambar serta pewarnaan flipchart. 3) Tahap pasca produksi, setelah flipchart selesai dalam bentuk pdf, selanjutnya merupakan proses percetakan dan perakitan. Flipchart dicetak menggunakan art carton dan art paper serta dirakit menggunakan spiral dan double tape. 3) Mengembangakan petunjuk Pada tahap pengembangan selanjutnya peneliti membuat lembar bantuan untuk guru sebagai pengguna. Adapun petunjuk penggunaannya sebagai berikut: a) Siapkan media pembelajaran visual flipchart motivasi berprestasi, b) Perhatikan posisi flipchart sehingga dapat dilihat dengan baik oleh semua peserta didik yang ada di ruangan kelas, c) Pengaturan peserta didik, untuk hasil yang lebih baik perlu pengaturan peserta didik, misalnya peserta didik dibentuk menjadi setengah lingkaran agar memperoleh pandangan yang baik. d) Materi yang disajikan terlebih dahulu diperkenalkan kepada peserta didik pada saat awal membuka pembelajaran, e) Buka lembaran demi lembaran untuk menjelaskan materi kepada peserta didik, f) Pada bagian belakang flipchart telah disediakan lembar bantuan untuk memudahkan guru dalam menjelaskan materi, g) Setelah flipchart selesai dipaparkan, berikan lembar kerja peserta didik untuk mengetahui hasil pembelajaran media flipchart (evaluasi). 4) Melakuikan evaluasi formatif: 
1 Hasil Validasi Ahli Media, penilaian ahli media pada media pembelajaran flipchart dilakukan oleh ahli media melalui kuesioner dengan menggunakkan angket. Berdasarkan rumus penghitungan nilai rata-rata pada evaluasi formatif maka didapatkan penghitungan sebagai berikut:

Tabel 1 Hasil validasi ahli media

\begin{tabular}{clll}
\hline No & Aspek & $\begin{array}{l}\text { Rata-rata } \\
\text { Presentase }\end{array}$ & Kategori \\
\hline 1 & Desain & & \\
2 & Materi & & Sangat \\
3 & Bahasa & $95 \%$ & Baik \\
4 & Tipografi & & \\
5 & Lay out & & \\
\hline 2 & Hasil Validasi Ahli Materi, uji coba ahli
\end{tabular}
selanjutnya adalah ahli materi, hasil dari uji coba yang dilakukan untuk pengembangan media pembelajaran flipchart untuk meningkatkan motivasi berprestasi diperoleh hasil sebagai berikut:

Tabel 4.2 Hasil validasi ahli materi

\begin{tabular}{llll}
\hline No & Aspek & $\begin{array}{c}\text { Rata-rata } \\
\text { presentase }\end{array}$ & Kategori \\
\hline 1 & Penilaian Isi & & \\
2 & Penilaian & & \\
& Kelayakan & & Sangat \\
& Penyajian & $98 \%$ & Baik \\
3 & Layanan & & \\
& informasi & & \\
& Motivasi & & \\
& Berprestasi & \\
\hline 3 & Melakukan pilot test, Hasil penilaian uji
\end{tabular}
coba peserta didik pengembangan media pembelajaran flipchart untuk meningkatkan motivasi berprestasi melalui layanan bimbingan kelompok mendapatkan rata-rata persentase $95 \%$ dengan kategori sangat baik.

Setelah diberikan perlakukan dengan memberikan media pembelajaran flipchart motivasi berprestasi, 10 peserta didik kembali mengerjakan kuesioner untuk meningkatkan motivasi berprestasi dilakukan untuk melihat perubahan peserta didik setelah mendapatkan materi dengan media pembelajaran flipchart. Hasil dari kuesioner untuk meningkatkan motivasi berprestasi yaitu:
$10 \%$ atau tak seorang pun mengetahui motivasi berprestasi, setelah diberikan media pembelajaran flipchart motivasi berprestasi presentase berubah menjadi $100 \%$ (10 peserta didik) atau seluruhnya mengetahui motivasi berprestasi.

$20 \%$ atau tak seorang pun menyatakan guru bimbingan dan konseling memberikan materi untuk meningkatkan motivasi berprestasi, setelah diberikan media pembelajaran flipchart motivasi berprestasi presentase berubah menjadi $100 \%$ (10 peserta didik) atau seluruhnya menyatakan guru bimbingan dan konseling memberikan materi untuk meningkatkan motivasi berprestasi

$3 \quad 100 \%$ (10 peserta didik) atau seluruhnya menyatakan enggan bersaing dengan teman-teman untuk mendapatkan nilai tertinggi dikelas, setelah diberikan media pembelajaran flipchart motivasi berprestasi presentase berubah menjadi $10 \%$ (1 peserta didik) atau sebagian kecil menyatakan enggan bersaing dengan teman-teman untuk mendapatkan nilai tertinggi dikelas.

$450 \%$ (5 peserta didik) atau setengahnya menyatakan tidak mempelajari bahasa asing yang tidak dimengerti, setelah diberikan media pembelajaran flipchart motivasi berprestasi presentase berubah menjadi $10 \%$ (1 peserta didik) atau sebagian kecil menyatakan tidak mempelajari bahasa asing yang tidak dimengerti.

$560 \%$ (6 peserta didik) atau sebagian besar menyatakan hanya menunggu pemberitahuan dari guru tentang hal-hal yang harus dipersiapkan dalam menghadapi ujian, setelah diberikan media pembelajaran flipchart motivasi berprestasi presentase berubah menjadi 20\% (2 peserta didik) atau sebagian kecil menyatakan hanya menunggu pemberitahuan dari guru tentang hal-hal yang harus dipersiapkan dalam menghadapi ujian.

$690 \%$ (9 peserta didik) atau hampir seluruhnya menyatakan mengumpulkan tugas seadanya tanpa memikirkan 
bagaimana hasilnya nanti, setelah diberikan media pembelajaran flipchart motivasi berprestasi presentase berubah menjadi $20 \%$ (2 peserta didik) atau sebagian kecil menyatakan mengumpulkan tugas seadanya tanpa memikirkan bagaimana hasilnya nanti.

$790 \%$ (9 peserta didik) atau hampir seluruhnya menyatakan tidak memeriksa kembali pekerjaan rumah setelah dinilai guru, setelah diberikan media pembelajaran flipchart motivasi berprestasi presentase berubah menjadi $20 \%$ (2 peserta didik) atau sebagian kecil menyatakan tidak memeriksa kembali pekerjaan rumah setelah dinilai guru.

8 Kuesioner yang diberikan kepada 10 peserta didik merupakan kuesioner yang telah dilakukan uji validitas tiap butir item pernyataan. Berdasarkan hasil uji validitas butir item yang dilakukan pada 35 peserta didik, dari 23 butir item pernyataan terdapat 7 butir item pernyataan yang tidak valid dan 7 butir item pernyataan yang tidak valid telah direvisi sebelum akhirnya kuesioner untuk meningkatkan motivasi berprestasi diberikan kepada sepuluh peserta didik.

\section{KESIMPULAN}

Berdasarkan hasil penelitian pengembangan media pembelajaran visual dengan menggunakan flipchart untuk meningkatkan motivasi berprestasi melalui layanan bimbingan kelompok dapat disimpulkan bahwa flipchart merupakan media yang bisa dikembangkan untuk memberikan informasi dengan tampilan yang menarik. Pengembangan media flipchart untuk meningkatkan motivasi berprestasi untuk kelas X di SMA Negeri 11 Jakarta telah memenuhi komponen yang sangat baik. Penyebaran kuesioner media pembelajaran flipchart untuk meningkatkan motivasi berprestasi juga diberikan kembali kepada 10 peserta didik melalui bimbingan kelompok, setelah diberi media pembelajaran flipchart untuk meningkatkan motivasi berprestasi hasilnya $100 \% \quad(10$ peserta didik) atau seluruhnya mengetahui media pembelajaran flipchart, $100 \%$ (10 peserta didik) atau seluruhnya menyatakan media flipchart adalah media yang mampu menyajikan pembelajaran secara ringkas dan praktis, $100 \%$ (10 peserta didik) atau seluruhnya menyatakan media flipchart adalah media yang fleksibel, dan 100\% (10 peserta didik) atau seluruhnya mengetahui cara menggunakan flipchart.

Pada kuesioner motivasi berprestasi hasilnya, 100\% (10 peserta didik) atau seluruhnya mengetahui motivasi berprestasi, 100\% (10 peserta didik) atau seluruhnya menyatakan guru bimbingan dan konseling memberikan materi untuk meningkatkan motivasi berprestasi, $10 \%$ (1 peserta didik) atau sebagian kecil menyatakan enggan bersaing dengan teman-teman untuk mendapatkan nilai tertinggi dikelas dan peserta didik lainnya berusaha untuk mendapatkan nilai tertinggi dikelas, 10\% (1 peserta didik) atau sebagian kecil menyatakan tidak mempelajari bahasa asing yang tidak dimengerti dan peserta didik lainnya mencoba untuk mempelajari bahasa asing, 20\% (2 peserta didik) atau sebagian kecil menyatakan hanya menunggu pemberitahuan dari guru tentang hal-hal yang harus dipersiapkan dalam menghadapi ujian dan peserta didik lainnya mencoba mencari tahu tentang hal-hal yang harus dipersiapkan dalam menghadapi ujian, 20\% (2 peserta didik) atau sebagian kecil menyatakan mengumpulkan tugas seadanya tanpa memikirkan bagaimana hasilnya nanti dan peserta didik lainnya berusaha untuk mengumpulkan tugas semaksimal mungkin, $20 \%$ (2 peserta didik) atau sebagian kecil menyatakan tidak memeriksa kembali pekerjaan rumah setelah dinilai guru dan peserta didik lainnya memeriksa pekerjaan rumahnya setelah dinilai oleh guru agar mengetahui kesalahan yang ia kerjakan. Media pembelajaran flipchart untuk meningkatkan motivasi berprestasi dikategoriikan sangat baik dan layak untuk menjadi media pembelajaran dan cocok 
untuk peserta didik yang memiliki gaya belajar visual.

\section{DAFTAR PUSTAKA}

Arsyad, A. (2013). Media pengajaran. Jakarta: Raja Grafindo.

McClelland, D. (1987). Human motivation. New York: Cambridge University Press.

Suarni, N. K. (2004). Meningkatkan motivasi berprestasi siswa Sekolah Menengah Umum di Bali dengan strategi pengelolaan diri model Yates: Studi kuasi eksperimentasi pada siswa kelas I SMU di Bali. (Unpublished doctoral dissertation). Universitas Gadjah Mada, Yogyakarta.

Sugiyono. (2009). Metode penelitian kuantitatif, kualitatif, dan $R \& D$. Bandung: Alfabeta.

Susilana, R., \& Riyana, C. (2008). Media pembelajaran: Hakikat pengembangan, pemanfaatan, dan penilaian. Bandung: Wacana Prima.

Usman, B. \& Asnawir. (2002). Media pembelajaran. Jakarta: Ciputat Pers.

Winkel. (2000). Psikologi pendidikan dan evaluasi belajar. Jakarta: Gramedia. 


\section{Lampiran}

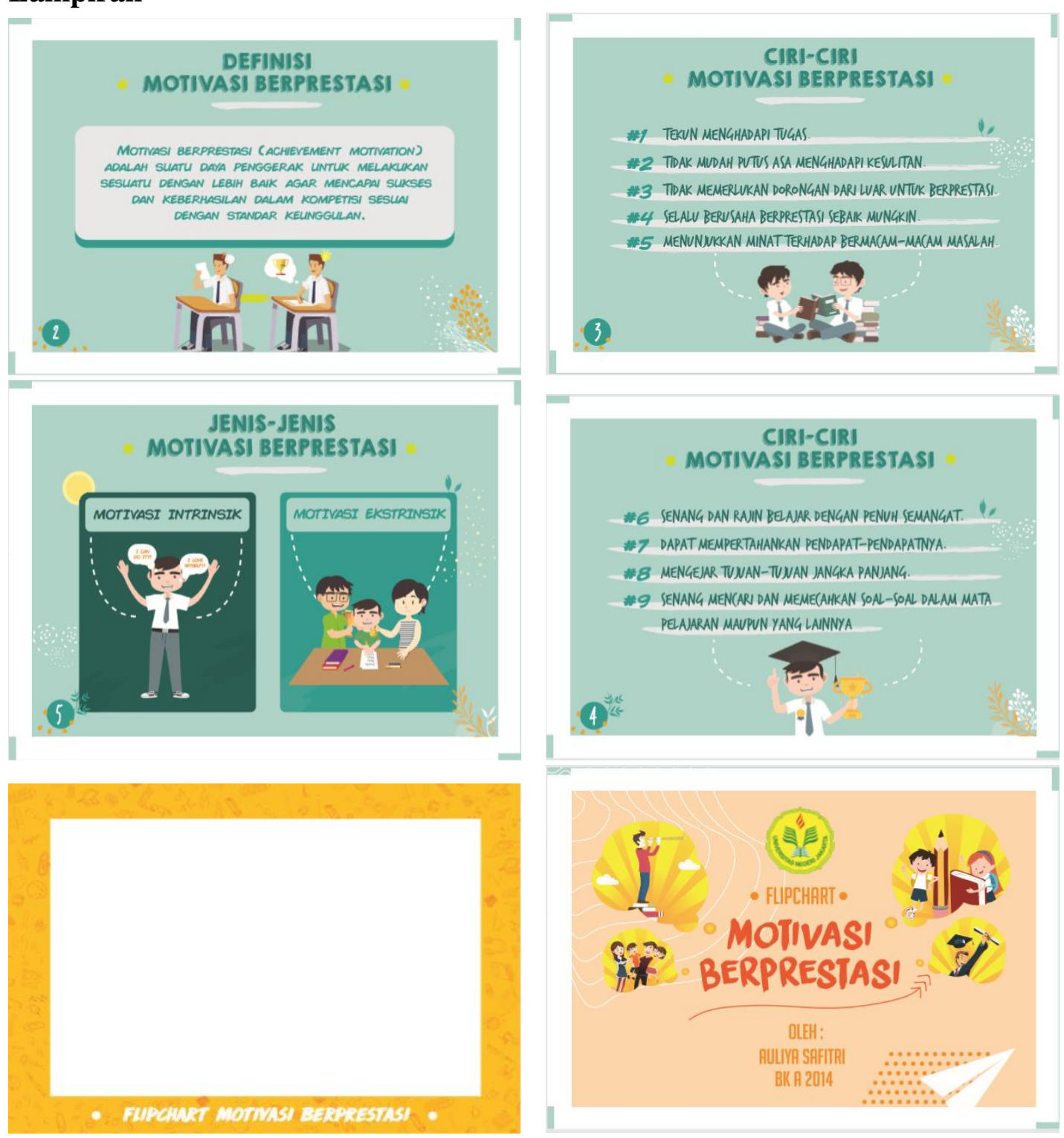

